\title{
Genetic Relationships among Xanthomonas Species and Pathovars Based on RFLP Analyses of PCR-amplified 16S, 23S rDNA and rDNA Internal Transcribed Spacer
}

\author{
Hirokazu OCHIAI ${ }^{* * *}$ and Hisatoshi $\mathrm{KAKU}^{*}$
}

\begin{abstract}
Phylogenetic relationships among 43 bacterial strains of Xanthomonas and two strains of Stenotrophomonas maltophilia were clarified by PCR-restriction fragment length polymorphism (RFLP) analyses of three DNA fragments corresponding to $16 \mathrm{~S}, 23 \mathrm{~S}$ rDNA and the 16S-23S rRNA internal transcribed spacer region (ITS) using ten restriction enzymes. From the data of the 16S rDNA RFLPs, seven genotypes were detected, while eight genotypes were observed based on the data of the 23S rDNA RFLPs among Xanthomonas strains tested. When the data of the $16 \mathrm{~S}$ and 23S rDNA RFLPs were combined, the Xanthomonas strains were divided into thirteen rDNA genotypes. Cluster analysis based on rDNA genotypes showed that they were divided into two groups designated as subgroups 1 and 2, which were distinguishable from the related genus Stenotrophomonas. On the basis of the ITS RFLPs, 20 types were observed, and two groups were formed. The members of each group were the same as those based on the rDNAs. The data suggests that this genus is phylogenetically grouped into at least two lineages.
\end{abstract}

(Received February 25, 1999 ; Accepted April 26, 1999)

Key words : Xanthomonas, PCR-RFLP, rrn operon.

\section{INTRODUCTION}

The genus Xanthomonas, which mostly comprises phytopathogenic bacteria, is a member of the family Pseudomonadaceae. Until early 1990, Xanthomonas was composed of seven species, Xanthomonas albilineans, $X$. axonopodis, $X$. campestris, $X$. fragariae, $X$. oryzae, $X$. populi and $X$. maltophilia ${ }^{28}$. In addition, most of the members of Xanthomonas were classified as pathovars of species of Xanthomonas campestris. Accordingly, Xanthomonas campestris contained more than 140 pathovars. The taxonomic complexity in Xanthomonas resulted because the taxon is mainly based on host specificity ; most of them can not be distinguished phenotypically ${ }^{24,27,30}$. In 1993, Palleroni and Bradbury ${ }^{19}$ proposed that $X$. maltophilia should be transferred to a separate new genus Stenotrophomonas because $X$. maltophilia is not a plant pathogen, although other members of Xanthomonas species cause diseases of diverse plants.

Currently, molecular techniques, such as RFLP analysis of genomic DNA ${ }^{1,3,4,17,22,32)}$ and PCR-amplified DNA $^{13,18)}$, DNA reassociation ${ }^{27,31)}$ and sequence analy$\mathrm{sis}^{6,14)}$ have been used in genetic diversity, identification and the taxonomy of Xanthomonas species. Recently, the genus Xanthomonas was reclassified into 20 genospecies by DNA reassociation ${ }^{27}$, which is, generally used for species delineation ${ }^{34)}$, and the $16 \mathrm{~S}$ rDNA sequences of these species were analyzed ${ }^{8}$. Thus, the phylogenetic relationships of the genus Xanthomonas are of interest.

At present, sequence analysis of ribosomal operons (called $r r n$ operons) is the method of choice to determine phylogenetic relationships among organisms ${ }^{35}$. These operons contain three genes, which code the $16 \mathrm{~S}$ rRNA gene (small subunit of ribosomal; rrs), the 23S rRNA gene (large subunit of ribosomal; $r r l$ ) and 5S rRNA gene. An internal transcribed spacer region called ITS (16S-23S spacer region) exists between $r r s$ and $r r l$. PCR-RFLP based on rrs has been used by several authors ${ }^{11,15,16,18,25,26,33)}$, because this method is useful and rapid for taxonomic and strain-typing purposes. In this study, therefore, PCR-amplified $r r s, r r l$ and ITS region ( $\mathrm{rrn}$ operon) of 43 strains from Xanthomonas species and two strains of Stenotrophomonas maltophilia were analyzed on the basis of their restriction fragment length polymorphisms (RFLPs) to determine phylogenetic relationships within the genus Xanthomonas.

\section{MATERIALS AND METHODS}

Bacterial strains Forty-three bacterial strains from Xanthomonas species, two strains of Stenotrophomonas maltophilia (previously, designated as Xanthomonas maltophilia) and four strains from Pseudomonas

\footnotetext{
* National Institute of Agro-biological Resources, Tsukuba 305-8602, Japan

** Corresponding author. 
species were used in this study. Information on bacterial strains is shown in Table 1.

Preparation of $\boldsymbol{D N A}$ Total bacterial DNA was prepared by using a CTAB extract method ${ }^{2}$. Briefly, cultures were incubated for $16 \mathrm{hr}$ at $28^{\circ} \mathrm{C}$ in $5 \mathrm{ml}$ of $\mathrm{LB}$ medium (10 g Bacto-tryptone, $5 \mathrm{~g}$ Bacto-yeast extract and $5 \mathrm{~g} \mathrm{NaCl}$ in 1 liter of distilled water). Cells were lysed by SDS, and the resulting lysate was treated with proteinase $\mathrm{K}$. DNA was purified with a solution of $\mathrm{CTAB} / \mathrm{NaCl}$ (10\% cetyltrimethylammonium bromide in $0.7 \mathrm{M} \mathrm{NaCl}$ ) followed by chloroform/isoamylalcohol $(24: 1)$ and phenol/chloroform/isoamylalcohol (25:

$24: 1)$ extractions. DNA was recovered by isopropanol precipitation and washed in $70 \%$ ethanol. The pellet was resuspended in $100 \mu \mathrm{l}$ of TE buffer $(10 \mathrm{mM}$ Tris- $\mathrm{HCl} \mathrm{pH}$ 8.0, $1 \mathrm{mM}$ EDTA pH 8.0) with addition of $1 \mu 1$ of ribonuclease $\mathrm{A}(10 \mathrm{mg} / \mathrm{ml})$ and stored at $4^{\circ} \mathrm{C}$.

PCR amplification The PCR primers used in this study were designed from the conserved regions in the 16S rRNA and 23S rRNA genes by comparing $E$. coli ${ }^{5}$ ) and Pseudomonas ${ }^{10,23)}$. Primers 1 F (5'-AGTTTGATCCTGGCTC-3' from position 10 to position 25 on $E$. coli) and 3R (5'-AAGGAGGTGATCCAGCC-3' from position 1525 to position 1541 on $E$. coli) amplified nearly the full length of the $16 \mathrm{~S}$ rRNA gene. Primer $4 \mathrm{~F}$ (5'-ACTAAGCGTACAGGTGGAT-3' from position 10 to position 29 on E. coli) and 1401R (5'-AAGTACAGGAATAATAAC-3' from position 1389 to position 1406 on $E$. coli) amplified approximately half the length of the 23S rRNA gene. Primers 2F (5'-TCAAATGAATTGACGGGGGC-3' from position 911 to position 930 on $E$. coli) and $5 \mathrm{R}\left(5^{\prime}\right.$ AAGTCGCTGACCCATTATAC-3' from position 570 to position 589 on $E$. coli) amplified the ITS region containing the $3^{\prime}$ end of $16 \mathrm{~S}$ rRNA gene and the $5^{\prime}$ end of $23 \mathrm{~S}$ rRNA gene. PCR amplification was performed with a GeneAmp PCR System 2400 (Perkin-Elmer Corp.) using Expand High Fidelity PCR System (Boehringer Mannheim). The PCRs were carried out in $100 \mu$ l reaction volume by mixing template DNA with reaction buffer containing $200 \mu \mathrm{M}$ of the deoxynucleotide triphosphate,

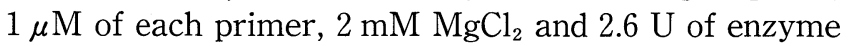
mix. Amplification followed the standard temperature profile: an initial denaturation at $95^{\circ} \mathrm{C}$ for $5 \mathrm{~min} ; 30$ cycles of denaturation at $94^{\circ} \mathrm{C}$ for $1 \mathrm{~min}$, annealing at $55^{\circ} \mathrm{C}$ for $2 \mathrm{~min}$ and extension at $72^{\circ} \mathrm{C}$ for $3 \mathrm{~min}$, and a final extension at $72^{\circ} \mathrm{C}$ for $7 \mathrm{~min}$. PCR products were analyzed by gel electrophoresis on $0.7 \%$ agarose (Agarose S; Nippon Gene) in 0.5 X TBE buffer $(45 \mathrm{mM}$ Tris-borate and $1 \mathrm{mM}$ EDTA). Gels were stained with ethidium bromide and photographed under UV illumination with Polaroid type 667 film.

Restriction fragment analysis Aliquots (5-10 $\mu 1)$ of PCR products were digested with $5 \mathrm{U}$ of restriction endonuclease (Nippon Gene, Takara Shuzo, and Toyobo) in $15 \mu 1$ reaction volume with manufacturer's recommended buffer and temperature. The following ten enzymes were used : AluI, DdeI, HaeIII, HhaI, HinfI, $M b o \mathrm{I}, M s p \mathrm{I}, M v a \mathrm{I}, N c i \mathrm{I}$, and $R s a \mathrm{I}$. In some cases, an additional nine restriction enzymes (AciI, BfaI, BstUI, Cfr13I, MaeI, MaeIII, NlaIII, TaqI, and TspEI) were used. Digested DNA was analyzed by gel electrophoresis on 2.5 to $3 \%$ agarose (NuSieve GTG ; FMC Bioproducts) in $0.5 \mathrm{X}$ TBE buffer. Electrophoreses were carried out in 15 -by $14-\mathrm{cm}$ gels, and the gels were stained and photographed as described earlier.

RFLP data analysis RFLP bands of each strain were coded in binary form by scoring the presence or absence of each band. Pairwise distances for each RFLP data set were computed with the Dice similarity coefficient (S) by using the WinDist program ${ }^{36}$. A dendrogram was constructed from the distance matrix $(D=$ $1-S$ ) data by UPGMA using the NEIGHBOR and DRAWGRAM program in PHYLIP package ${ }^{7}$. The confidence limits of dendrograms were determined by bootstrap analysis with 1000 replications using the WinBoot program ${ }^{36)}$

\section{RESULTS}

\section{PCR amplification}

All 49 strains tested were amplified with the primers used. They produced a single band with each primer set, and these sizes corresponded to the expected sizes of the targeted 16S rRNA and 23S rRNA genes, respectively (data not shown). For the ITS region, they produced a band of approximately $1600 \mathrm{bp}$, and the resulting size of the ITS region ranged from 500 to $550 \mathrm{bp}$. It was the expected size, since we have recently determined the sequences of this region among Xanthomonas strains (unpublished data).

\section{RFLP analysis of amplified 16S rRNA gene}

Restriction fragments shorter than approximately 100 bp were not well-resolved by electrophoresis in $2.5-3 \%$ agarose. Three to nine restriction fragments were observed with each of the 10 restriction endonucleases in the amplified $16 \mathrm{~S}$ rDNAs. Among strains of Xanthomonas and $S$. maltophilia, two to five distinct restriction patterns were detected with seven enzymes. Digestion with the following three enzymes, HhaI, HinfI and RsaI, did not produce any polymorphism among Xanthomonas and S. maltophilia strains used. Representative restriction patterns of 10 enzymes are shown in Fig. 1A.

The $16 \mathrm{~S}$ genotypes which represent the combination of restriction patterns obtained with 10 restriction enzymes are shown in Table 2. The differences in patterns among the Xanthomonas and S. maltophilia strains tested were mainly caused by band shifts and, therefore, other band patterns were similar to each other (Fig. 1A). The restriction patterns of four strains of Acidovorax avenae (Pseudomonas avenae), Burkholderia glumae (Pseudomonas glumae), Pseudomonas fuscovaginae and Pseudomonas syringae pv. oryzae were distinctly different from those of Xanthomonas and Stenotrophomonas species (Fig. 1A). The combined results revealed that there were seven genotypes ( 1 to 7 ) in Xanthomonas, two genotypes (8 and 9) in Stenotro- 
Table 1. RFLP types of Xanthomonas, Stenotrophomonas and Pseudomonas strains used in this study

\begin{tabular}{|c|c|c|c|c|c|c|}
\hline Species or pathovars & Strain $^{\text {a) }}$ & $\begin{array}{l}\text { 16S rDNA } \\
\text { genotype }^{\text {b) }}\end{array}$ & $\begin{array}{l}\text { 23S rDNA } \\
\text { genotype }^{c}\end{array}$ & $\begin{array}{c}\text { rDNA } \\
\text { genotype }^{\mathrm{d}}\end{array}$ & subgroup $^{\mathrm{e})}$ & $\begin{array}{l}\text { ITS } \\
\text { type }^{\text {f) }}\end{array}$ \\
\hline Xanthomonas albilineans & ATCC $33915^{\mathrm{T}}$ & 5 & 5 & 11 & 2 & 19 \\
\hline Xanthomonas axonopodis & ATCC $19312^{\mathrm{T}}$ & 2 & 6 & 10 & 1 & 18 \\
\hline Xanthomonas fragariae & ATCC $33239^{\mathrm{T}}$ & 1 & 1 & 1 & 1 & 20 \\
\hline \multicolumn{7}{|l|}{ Xanthomonas oryzae pathovars } \\
\hline pv. oryzae & ATCC $35933^{\mathrm{T}}$ & 1 & 1 & 1 & 1 & 2 \\
\hline pv. orizicola & NCPPB $1585^{*}$ & 1 & 1 & 1 & 1 & 3 \\
\hline \multicolumn{7}{|l|}{ Xanthomonas campestris pathovars } \\
\hline \multirow[t]{2}{*}{ pv. alfalfae } & ATCC 11765 & 2 & 2 & 4 & 1 & 5 \\
\hline & MAFF 301090 & 2 & 2 & 4 & 1 & \\
\hline pv. begoniae & ATCC 8718 & 2 & 1 & 6 & 1 & 4 \\
\hline \multirow[t]{2}{*}{ pv. campestris } & ATCC $33913^{\mathrm{T}}$ & 1 & 1 & 1 & 1 & 3 \\
\hline & $\mathrm{XCC} 91-\mathrm{N} 1$ & 1 & 1 & 1 & 1 & 2 \\
\hline pv. cannabis & MAFF 301606 & 1 & 2 & 2 & 1 & \\
\hline \multirow{2}{*}{ pv. carotae } & ATCC 10547 & 1 & 1 & 1 & 1 & 6 \\
\hline & MAFF 301101 & 1 & 1 & 1 & 1 & \\
\hline pv. cerealis & NCPPB $1944^{*}$ & 3 & 3 & 3 & 2 & 7 \\
\hline \multirow{2}{*}{ pv. citri } & MAFF 301077 & 1 & 2 & 2 & 1 & \\
\hline & NCPPB $409^{*}$ & 1 & 2 & 2 & 1 & 1 \\
\hline pv. coriandri & ATCC $17996^{*}$ & 2 & 2 & 4 & 1 & 8 \\
\hline \multirow[t]{2}{*}{ pv. cucurbitae } & ATCC 23378 & 1 & 1 & 1 & 1 & 9 \\
\hline & MAFF 301081 & 1 & 1 & 1 & 1 & \\
\hline \multirow[t]{3}{*}{ pv. dieffenbachiae } & ATCC 23379 & 4 & 4 & 7 & 1 & 10 \\
\hline & MAFF 301636 & 1 & 2 & 2 & 1 & \\
\hline & MAFF 301642 & 1 & 1 & 1 & 1 & \\
\hline \multirow[t]{2}{*}{ pv. glycines } & MAFF 301091 & 1 & 2 & 2 & 1 & \\
\hline & NCPPB $554^{*}$ & 1 & 2 & 2 & 1 & 1 \\
\hline pv. graminis & ATCC $29091^{*}$ & 3 & 3 & 3 & 2 & 11 \\
\hline \multirow[t]{2}{*}{ pv. hyacinthi } & ATCC $19314^{*}$ & 5 & 3 & 8 & 2 & 12 \\
\hline & MAFF 301390 & 5 & 3 & 8 & 2 & \\
\hline \multirow[t]{2}{*}{ pv. incanae } & ATCC $13462^{*}$ & 1 & 1 & 1 & 1 & \\
\hline & MAFF 210260 & 1 & 1 & 1 & 1 & \\
\hline pv. malvacearum & ATCC 9924 & 6 & 2 & 5 & 1 & 1 \\
\hline pv. mangiferaeindicae & ATCC $11637^{*}$ & 7 & 2 & 9 & 1 & 13 \\
\hline pv. nigromaculans & ATCC $23390^{*}$ & 1 & 1 & 1 & 1 & 14 \\
\hline pv. phaseoli & ATCC $9563^{*}$ & 1 & 2 & 2 & 1 & 4 \\
\hline pv. physalidicola & MAFF $301206^{*}$ & 2 & 7 & 12 & 1 & \\
\hline \multirow[t]{2}{*}{ pv. pruni } & ATCC $19316^{*}$ & 1 & 1 & 1 & 1 & 15 \\
\hline & MAFF 301420 & 1 & 1 & 1 & 1 & \\
\hline \multirow[t]{2}{*}{ pv. translucens } & ATCC $19319^{*}$ & 3 & 3 & 3 & 2 & 16 \\
\hline & MAFF 301035 & 3 & 3 & 3 & 2 & \\
\hline \multirow[t]{2}{*}{ pv. vesicatoria } & ATCC 35937 & 1 & 1 & 1 & 1 & 17 \\
\hline & MAFF 301256 & 1 & 8 & 13 & 1 & \\
\hline pv. vitians & ATCC $19320^{*}$ & 6 & 2 & 5 & 1 & 1 \\
\hline pv. zantedschiae & MAFF 301639 & 1 & 1 & 1 & 1 & \\
\hline pv. zinniae & MAFF 302064 & 1 & 1 & 1 & 1 & \\
\hline \multirow[t]{2}{*}{ Stenotrophomonas maltophilia } & MAFF 301689 & 8 & 9 & 14 & & \\
\hline & MAFF 520051 & 9 & 10 & 15 & & \\
\hline Pseudomonas fuscovaginae & MAFF 301178 & 12 & 11 & 16 & & \\
\hline Pseudomonas syringae pv. oryzae & MAFF 301530 & 13 & 12 & 17 & & \\
\hline Acidovarax avenae & MAFF 301150 & 10 & & & & \\
\hline Burkholderia glumae & MAFF 301169 & 11 & & & & \\
\hline
\end{tabular}

a) Abbreviations: ATCC, American Type Culture Collection, Rockville, Md. ; MAFF, Ministry of Agriculture, Forestry and Fisheries, Tsukuba, Japan; NCPPB, National Collection of Plant Pathogenic Bacteria, Harpenden, UK ; T, type strains and $*$, pathovar reference strains.

b) $16 \mathrm{~S}$ rDNA genotypes are defined in footnote a in Table 2.

c) $23 \mathrm{~S}$ rDNA genotypes are defined in footnote a in Table 2.

d) rDNA genotypes are defined by the combination of $16 \mathrm{~S}$ and $23 \mathrm{~S}$ rDNA types in Table 2.

e) Subgroups are defined by cluster analysis based on the combination of PCR-RFLP of 16S and 23S rDNA in Fig. 4.

f) ITS types are defined in footnote a in Table 2. 
Alul Haell Hhal Hinfl Mbol Mspl Mval Ncil Rsal Ddel MABCD EFGH MABCDEFG MABCD MABCDE MABCDEFG MABCDEF MABCDEF MABCDEF MABCD M ABC D E F
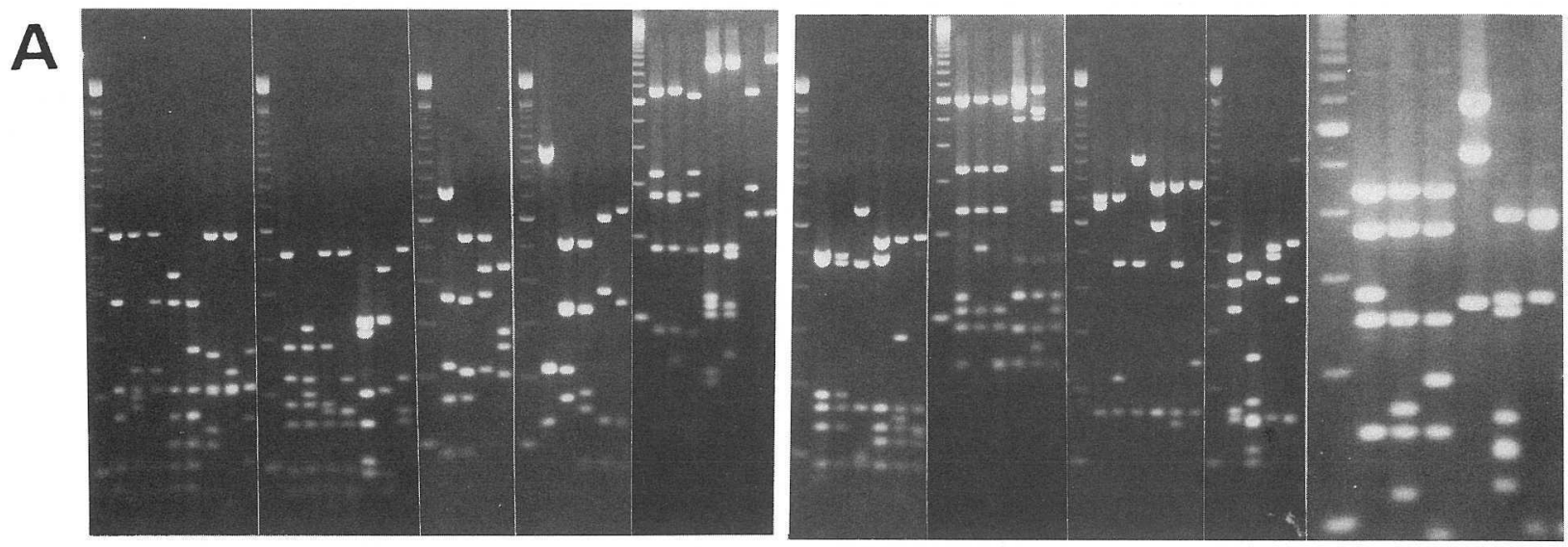

Alul Ddel Haelll Hhal Hinfl Mbol Mspl Mval Ncil Rsal

MABCD MABCDEF MABCD MABCDEF MABC MABC MABCDE ABCDEM MABCDEF MABCDEFG

B
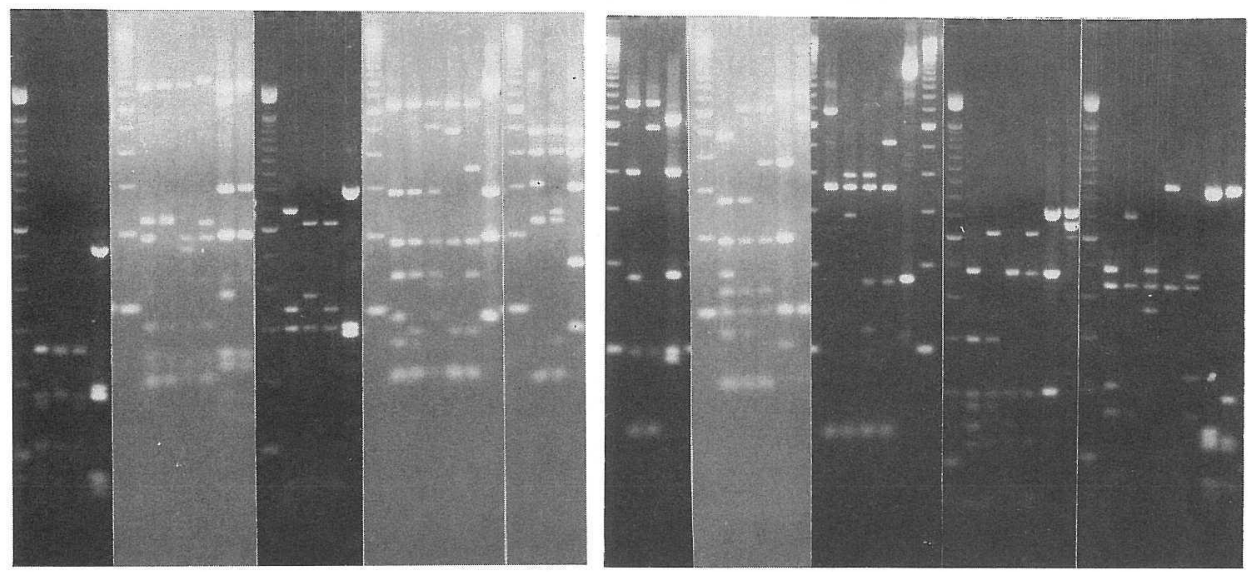

Fig. 1. Representative patterns of PCR-amplified 16S (A) and 23S rRNA (B) genes digested with ten endonucleases. The lane assignments (lanes $\mathrm{A}$ to $\mathrm{G}$ ) are given in Table 2. Lane M, molecular weight marker (100 bp ladder, Gibco-BRL).

phomonas and four genotypes (10 to 13) in Pseudomonas (Table 2).

The genotypes of S. maltophilia, A. avenae, B. glumae, $P$. fuscovaginae and $P$. syringae pv. oryzae were different from those of Xanthomonas species. Thirty-eight strains of Xanthomonas campestris pathovars tested were divided into seven genotypes (Table 1). Genotype 1 was dominant and included three species, $X$. campestris, $X$. fragariae and $X$. oryzae. Genotype 2 was shared with two species, $X$. axonopodis and $X$. campestris. Similarly, genotype 5 was shared with two species, $X$. albilineans and $X$. campestris. Genotypes $3,4,6$ and 7 were occupied with a single species $X$. campestris. Genotypes 4 and 7 were unique genotypes observed in $X . \quad c$. pv. dieffenbachiae and X.c. pv. mangiferaeindicae, respectively. Intraspecies variation was observed in only one pathovar, X. c. pv. dieffenbachiae which was divided into two genotypes, 1 and 4 . In addition, the digestion of amplified 16S rDNA with MspI or NciI discriminated Xanthomonas from Stenotrophomonas.

\section{RFLP analysis of amplified 23S rRNA gene}

Based on the analysis of amplified 23S rDNAs, four to eight restriction fragments were observed with each of the 10 restriction endonucleases used. Similarly, two to five distinct restriction patterns were detected with all 10 enzymes among strains of Xanthomonas and $S$. maltopholia tested here. Representative restriction patterns are shown in Fig. 1B. The 23S genotypes, which represent the combination of restriction patterns obtained with 10 restriction enzymes are shown in Table 2. The differences in patterns among Xanthomonas and S. maltopholia strains tested were also caused by band shifts (Fig. 1B). Other band patterns were similar to each other. The restriction patterns of $P$. fuscovaginae and $P$. syringae pv. oryzae were different from those of Xanthomonas and Stenotrophomonas strains (Fig. 1B). The 
Table 2. Summary of RFLP types

\begin{tabular}{|c|c|c|c|c|}
\hline \multirow{3}{*}{ Genotype $^{\text {a) }}$} & \multirow{3}{*}{$\begin{array}{c}\text { No. of } \\
\text { strains } \\
\text { (16S/23S/ITS) }\end{array}$} & \multicolumn{3}{|c|}{ Restriction patterns $^{\text {b) }}$ of amplified $16 \mathrm{~S}, 23 \mathrm{~S}$ rDNA genes and ITS digested with } \\
\hline & & $16 \mathrm{~S}$ & $23 \mathrm{~S}$ & ITS \\
\hline & & ADHHHMMMNR & ADHHHMMMNR & ADHHHMMMNR \\
\hline 1 & $26 / 19 / 4$ & AAAAAAAAAA & AAAAAAAAAA & AABAAABAAA \\
\hline 2 & $6 / 13 / 3$ & AAAAABAAAA & AAAAAABABB & AAAABAAAAA \\
\hline 3 & $4 / 6 / 2$ & CBBAAAABAA & BABBBAABAC & BAAABAAAAA \\
\hline 4 & $1 / 1 / 2$ & ACAAABAAAA & ABAAAABABB & BDDAABBAAA \\
\hline 5 & $3 / 1 / 1$ & BBBAAAABAA & $\mathrm{BABBBABBBD}$ & DCBAABDAAA \\
\hline 6 & $2 / 1 / 1$ & BAAAAAAAAA & ACAAAAAAAA & AAAABAAAAC \\
\hline 7 & $1 / 1 \% 1$ & AAAAAC AAAA & CAAAAABABB & CECBCCCBBD \\
\hline 8 & $1 / 1 / 1$ & DACAAABABA & AAAAAAAACA & BC BAABBAAA \\
\hline 9 & $1 / 1 / 1$ & EADAAACCCA & $\mathrm{AACCBACCDE}$ & BF AABDAAAE \\
\hline 10 & $1 / 1 / 1$ & FDEBBDDDDB & BDBDBBCDDD & BGBAAEBAAA \\
\hline 11 & $1 / 1 / 1$ & GEFCCEEEEC & DEDECCDEEF & СНCCCCCBBB \\
\hline 12 & $1 / 1 / 1$ & HFGDDFFFFD & DFDECCEEFG & EI CBCCCBBB \\
\hline 13 & $1 /-/ 1$ & HFGDEGFFFD & & ABBAAABAAA \\
\hline 14 & $-/-/ 1$ & & & BAAABDAAAA \\
\hline 15 & $-/-/ 1$ & & & ABAADDAAAA \\
\hline 16 & $-/-/ 1$ & & & CECCCCCBBB \\
\hline 17 & $-/-/ 1$ & & & ABAABDAAAF \\
\hline 18 & $-/-/ 1$ & & & BJ BAAABAAA \\
\hline 19 & $-/-/ 1$ & & & FKEDEFECCA \\
\hline 20 & $-/-/ 1$ & & & GLAEF BDAAA \\
\hline
\end{tabular}

a) Genotype represents the combination of restriction patterns obtained with the 10 restriction enzymes used in $16 \mathrm{~S}$, $23 \mathrm{~S}$ rDNA and ITS PCR-RFLP analyses.

b) A to $\mathrm{L}$ denote the types of restrictions patterns for the restriction enzyme as follows: The ADHHHMMMNR column indicates the restriction patterns (Figs. 1 and 2) obtained, respectively, with the endonucleases AluI, DdeI, HaeIII, HhaI, HinfI, MboI, MspI, MvaI, NciI and RsaI used for PCR-RFLP analysis.

combined results showed that there were eight genotypes (1 to 8) in Xanthomonas, two (9 and 10) in Stenotrophomonas and two (11 and 12) in Pseudomonas (Table 2). None of these genotypes, except for genotype 1, were shared with the two Xanthomonas species (Table 1). The thirty-eight tested strains of Xanthomonas campestris pathovars were divided into six genotypes (Tables 1 ; genotypes $1,2,3,4,7,8)$. Genotype 1 , containing 19 strains, was dominant and shared with three species, $X$. campestris, $X$. fragariae and $X$. oryzae. Genotypes 4, 5 and 6 were specific to genotypes observed in $X$. c. pv. dieffenbachiae (ATCC 23379), X. albilineans and $X$. axonopodis, respectively. Intraspecies variation was also observed in $X$. c. pv. dieffenbachiae, which was divided into three genotypes 1,2 and 4, respectively. In contrast with $16 \mathrm{~S}$ rDNA analysis, digestion of amplified $23 \mathrm{~S}$ rDNA with four enzymes $H h a \mathrm{I}, M s p \mathrm{I}, M v a \mathrm{I}$ or $\mathrm{Nci}$ I allowed to discriminate Xanthomonas from Stenotrophomonas.

\section{rDNA genotype}

Based on the combined data of $16 \mathrm{~S}$ and $23 \mathrm{~S}$ rDNA analyses, thirteen rDNA genotypes (1 to 13 ) were observed in 43 tested strains of Xanthomonas and were distinguishable from those (14 and 15) of the Stenotrophomonas strains (Table 1). None of these genotypes, except for rDNA genotype 1, were shared with two Xanthomonas species. The combined results of the $16 \mathrm{~S}$ and $23 \mathrm{~S}$ rDNA analyses also revealed that the same genotype was shared with different species or pathovars. For example, genotype 1 was the dominant type and included 10 pathovars of $X$. campestris, and two pathovars of $X$. oryzae and $X$. fragariae.

\section{RFLP analysis of amplified ITS region}

Analysis of the ITS regions containing the $3^{\prime}$ end of $16 \mathrm{~S}$ rDNA and the $5^{\prime}$ end of $23 \mathrm{~S}$ rDNA using 27 strains of Xanthomonas showed 3 to 12 different patterns with each of the 10 restriction endonucleases used. Partial results are shown in Fig. 2. The combined results using 10 enzymes indicated that there were 20 different types in the ITS region (Table 2). None of these ITS types were common to two species, although $X$. oryzae. pv. oryzae and $X$. campestris pv. campestris (XCC 91-N1) in type 2 and $X$. o. pv. oryzicola and $X$. c. pv. campestris (ATCC 33913) in type 3 were exceptional cases (Table 1). Twenty-two strains of Xanthomonas campestris pathovars tested were divided into 17 ITS types. These results showed that the ITS region was highly variable, although same ITS types were also shared with two (type 4) to four (type 1) pathovars. Most of the Xanthomonas strains tested could be discriminated at the level pathovar or species based on these three PCR-RFLP analyses. However, some strains could not be distinguished from $X$. campestris pv. campestris, $X$. c. pv. citri, $X$. c. pv. glycines, $X$. c. pv. malvacearum, $X$. c. pv. vitians, $X$. oryzae pv. oryzae and $X$. o. pv. oryzicola.

Further RFLP analysis using nine restriction enzymes 

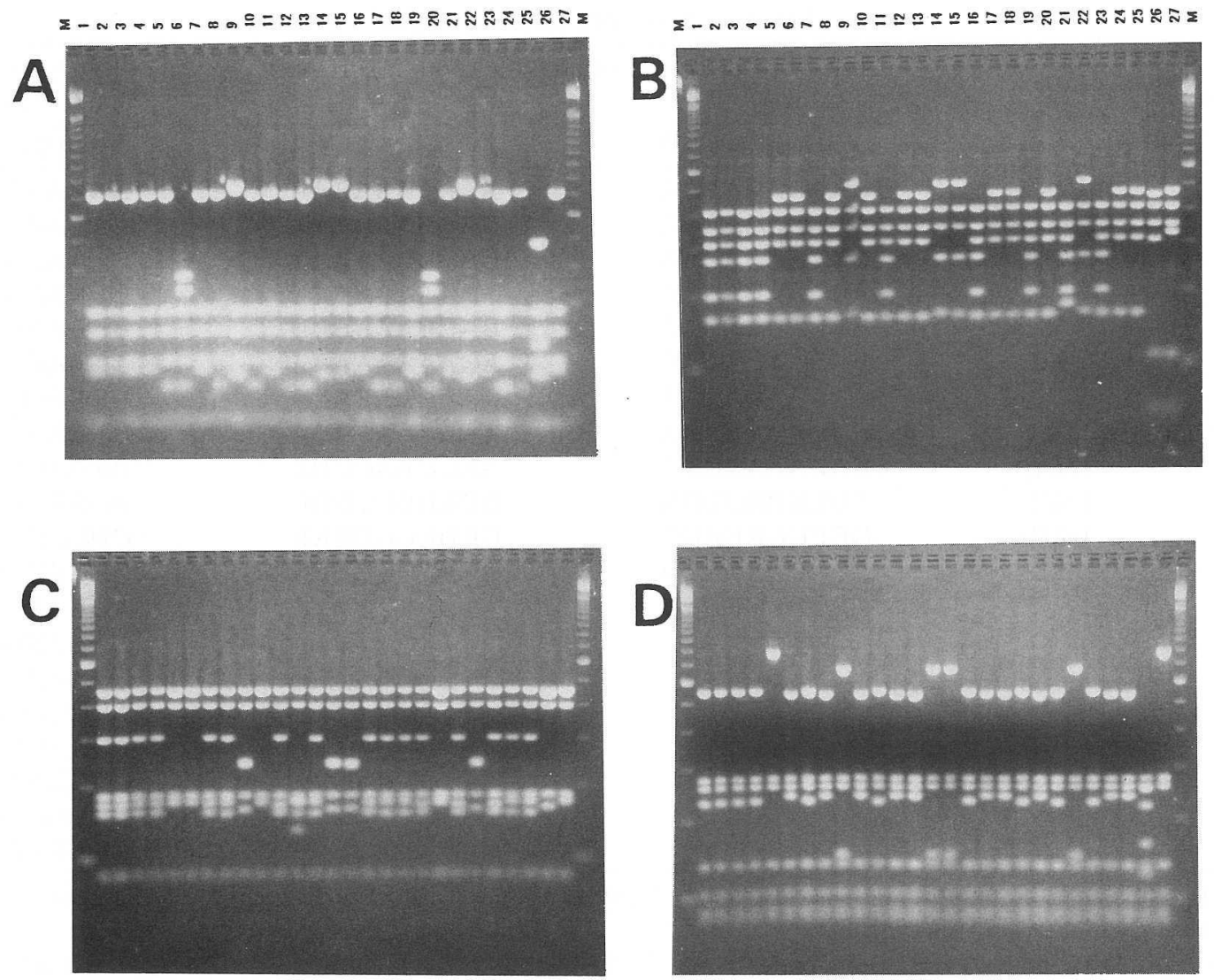

Fig. 2. Restriction patterns of PCR-amplified ITS digested with HaeIII (A), HinfI (B), MboI (C), and MspI (D). Lanes : 1, ATCC 35933 ; 2, NCPPB 1585 ; 3, ATCC 33913 ; 4, XCC 91-N1; 5, ATCC $11765 ; 6$, ATCC 8718; 7, ATCC 10547 ; 8, NCPPB 409 ; 9, NCPPB $1944 ; 10$, ATCC17996; 11, ATCC $23378 ; 12$, ATCC $23379 ; 13$, NCPPB 554 ; 14, ATCC 29091 ; 15, ATCC 19314 ; 16, ATCC 13462 ; 17, ATCC 9924 ; 18, ATCC 11637 ; 19, ATCC 23390 ; 20 , ATCC 9563 ; 21 , ATCC 19316 ; 22, ATCC 19319; 23, ATCC 35937 ; 24, ATCC $19320 ; 25$, ATCC $19312 ; 26$, ATCC $33915 ; 27$, ATCC 33239 ; M, molecular weight marker (100 bp ladder, Gibco-BRL).

Table 3. Detailed ITS types and restriction patterns with nine other enzymes

\begin{tabular}{|c|c|c|c|c|c|}
\hline \multirow[t]{2}{*}{ Species or pathovars } & \multirow[t]{2}{*}{ Strain } & \multirow{2}{*}{$\begin{array}{l}\text { Detailed } \\
\text { type }\end{array}$} & $\begin{array}{l}\text { Restriction patterns }{ }^{\text {a) }} \text { of amplified ITS } \\
\text { digested with nine other enzymes }\end{array}$ & \multirow{2}{*}{$\begin{array}{l}\text { Initial } \\
\text { type }^{\text {b) }}\end{array}$} & \multirow{2}{*}{$\begin{array}{l}\text { rDNA } \\
\text { genotype }\end{array}$} \\
\hline & & & ABBCMMNTT & & \\
\hline$X$. oryzae pv. pryzae & ATCC 35933 & $2 \mathrm{~A}$ & 111111211 & 2 & 1 \\
\hline$X$. campestris pv. campestris & XCC 91-N1 & $2 \mathrm{~B}$ & 111111311 & 2 & 1 \\
\hline$X$. oryzae pv. oryzicola & NCPPB 1585 & $3 \mathrm{~A}$ & 111111211 & 3 & 1 \\
\hline$X$. campestris pv. campestris & ATCC 33913 & $3 B$ & 111112311 & 3 & 1 \\
\hline \multirow{4}{*}{$\begin{array}{l}X . \text { campestris pv. citri } \\
\text { pv. glycines } \\
\text { pv. malvacearum } \\
\text { pv. vitians }\end{array}$} & NCPPB 409 & $1 \mathrm{~A}$ & 111111111 & 1 & 2 \\
\hline & NCPPB 554 & $1 \mathrm{~A}$ & 111111111 & 1 & 2 \\
\hline & ATCC 9924 & $1 \mathrm{~A}$ & 111111111 & 1 & 2 \\
\hline & ATCC 19320 & $1 \mathrm{~A}$ & 111111111 & 1 & 5 \\
\hline
\end{tabular}

a) 1 to 3 denote the types of restriction patterns for the restriction enzyme as follows. The ABBCMMNTT column indicates the restriction patterns obtained, respectively, with the endonucleases AciI, BfaI, Bst UI, Cfr 131, MaeI, MaeIII, NlaIII, TaqI and TspEI used for PCR-RFLP analysis.

b) Initial type corresponds to ITS types defined in footnote a in Table 2.

for the ITS region showed that strains belonging to the rDNA genotype $1, X$. c. pv. campestris, $X$. o. pv. oryzae and $X$. o. pv. oryzicola were distinguishable from each other (Table 3). But X. c. pv. citri and pv. glycines of rDNA genotype 2, and $X$. c. pv. malvacearum and pv. vitians of rDNA genotype 5 were not distinguishable by this analysis (Table 3). Therefore, these four pathovars appeared to be genetically closely related to each other.

Cluster analysis of combined 165 and 235 rDNA RFLPs

To estimate the relationships between the 17 rDNA genotypes, cluster analysis was performed based on the 


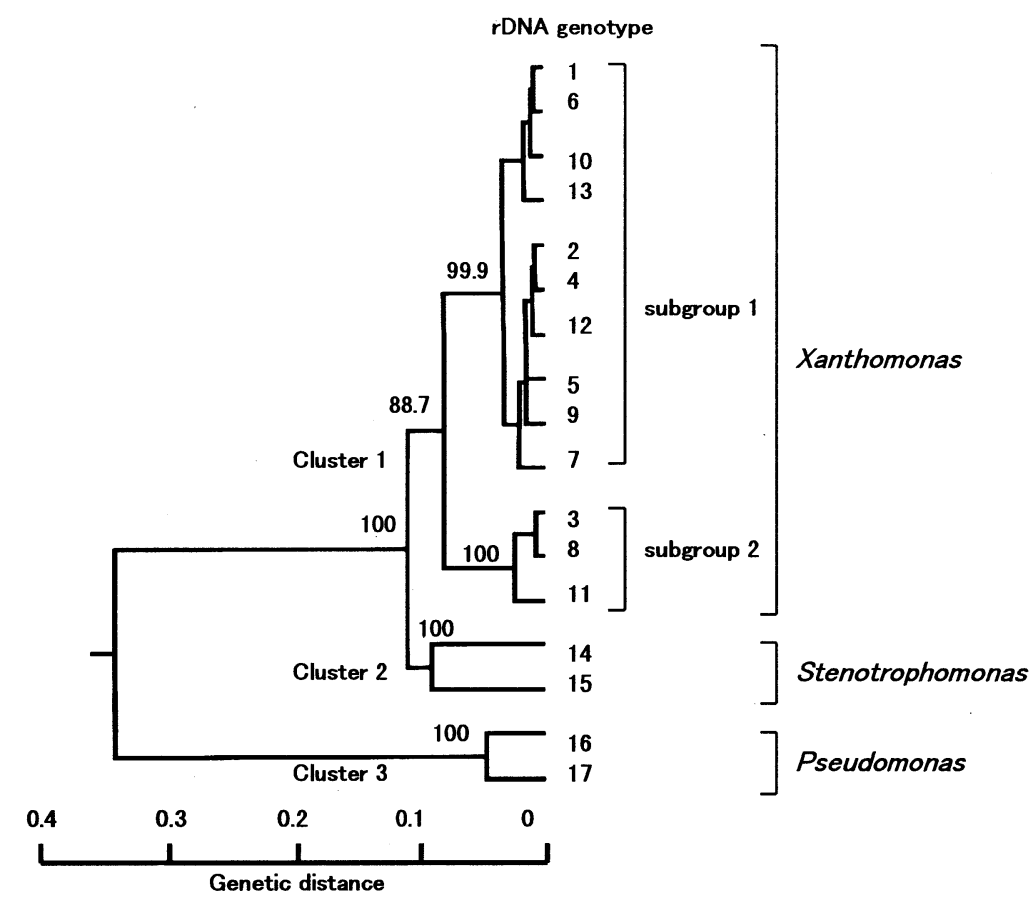

Fig. 3. Dendrogram constructed with UPGMA on the basis of the combined data set of $16 \mathrm{~S}$ and $23 \mathrm{~S}$ rDNA restriction patterns. The rDNA genotypes ( 1 to 17 ) are defined in Table 1 . The numbers shown next to the nodes indicate percent bootstrap values of the 1000 replicates.

combined data sets of the $16 \mathrm{~S}$ and $23 \mathrm{~S}$ rDNA restriction patterns by using UPGMA (Fig. 3). The obtained dendrogram showed that all the Xanthomonas strains tested here were grouped into the same cluster (cluster 1). The bootstrap results are indicated on the dendrogram in Fig. 3. The bootstrap value for the branch of clusters 1 and 2 was $100 \%$, indicating that these two clusters are phylogenetically separated, although these clusters are more closely related than cluster 3 (Pseudomonas cluster). Cluster 1 was composed of two groups designated as subgroups 1 and 2 . The bootstrap values for the internal branch of subgroups 1 and 2 were 99.9 and $100 \%$, respectively, indicating that these were very strong subclusters, although the bootstrap value for the branch of subgroups 1 and 2 was relatively low (88.7\%). Members of subgroup 1 were composed of rDNA genotypes 1, 2, 5, 6, 7, 9, 10, 12 and 13 defined in Table 1 . This group included 21 pathovars of $X$. campestris and two pathovars each of $X$. oryzae, $X$. axonopodis and $X$. fragariae. Members of subgroup 2 were composed of rDNA genotypes 3, 8 and 11 defined in Table 1 . Strains within this group were $X$. albilineans and four pathovars of $X$. campestris. The four pathovars of $X$. campestris belonging to subgroup 2 were pathovars cerealis, graminis, hyacinthi and translucens.

\section{Cluster analysis of ITS region RFLPs}

Based on the analysis of the ITS region, the obtained dendrogram indicated that the genetic distance was much greater than that by analysis of rDNA (Fig. 4). Xanthomonas strains tested here were divided into two groups designated as clusters 1 and 2 . Clusters 1 fell into the subgroups 1 of the analysis of combined $16 \mathrm{~S}$ and $23 \mathrm{~S}$

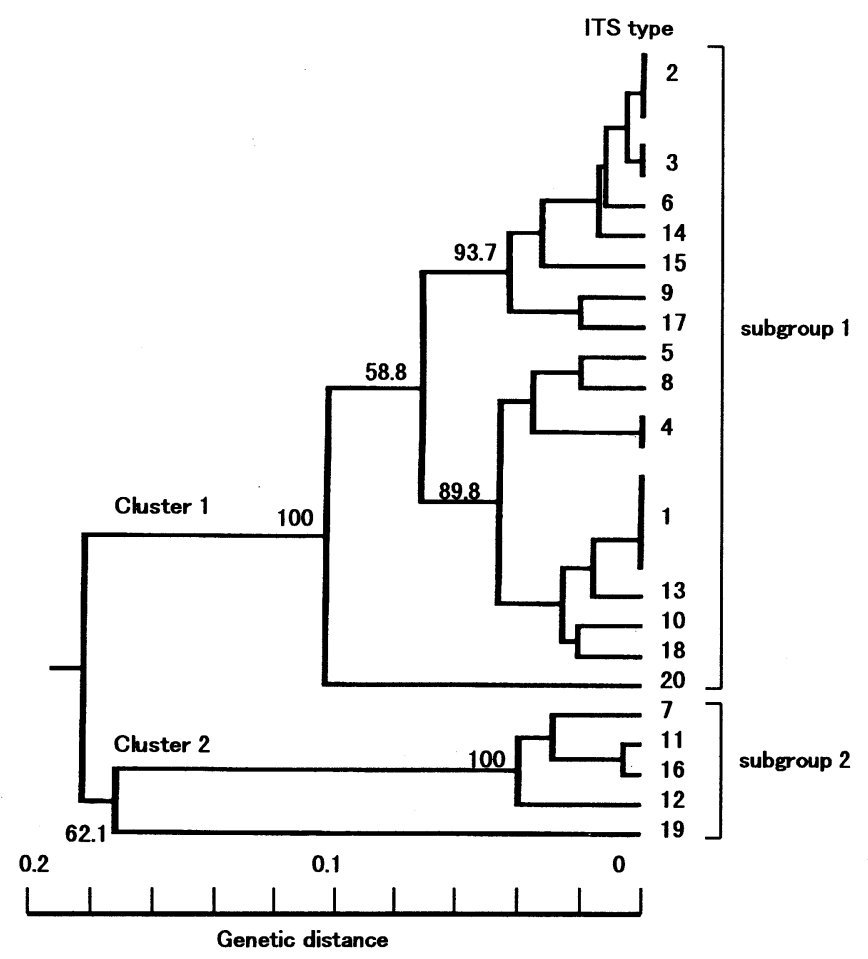

Fig. 4. Dendrogram constructed with UPGMA on the basis of ITS restriction patterns. The ITS types (1 to 20) are defined in Table 2. The numbers shown next to the nodes indicate percent bootstrap values of the 1000 replicates.

rDNA RFLPs, while cluster 2 fell into subgroup 2. The bootstrap results were illustrated on the dendrogram in Fig. 4. The bootstrap value of cluster 1 was $100 \%$, 
indicating that it was a very strong cluster. The bootstrap values for internal branches of cluster 1 were less than $94 \%$, indicating that the interrelationships among the strains within cluster 1 were not clear. The bootstrap value of cluster 2 was unexpectedly low (62.1\%). Within this cluster, ITS types 7, 11, 12 and 16 were more closely related to each other, with a bootstrap value of $100 \%$.

\section{DISCUSSION}

We showed that the PCR-RFLP analysis of the $r r n$ operon is a simple and rapid technique to evaluate phylogenetic relationships among strains of Xanthomonas and the related genus Stenotrophomonas. On the basis of the combination of PCR-RFLP of $16 \mathrm{~S}$ and $23 \mathrm{~S}$ rDNA, Xanthomonas strains tested here fell into the same cluster, which is distinguishable from the cluster of Stenotrophomonas. The bootstrap value for this branch is $100 \%$, indicating that the genera Xanthomonas and Stenotrophomonas are phylogenetically separable. It agreed with the previous report demonstrating that the PCR-RFLP of the amplified the $16 \mathrm{~S}$ rRNA gene could distinguish the genus Strenotrophomonas from the genus Xanthomonas $^{18)}$. Comparative RFLP analysis of the two genera with those of the Pseudomonas strains tested here, however, showed that Xanthomonas and Stenotrophomonas were relatively closely related. Hauben et al. ${ }^{8)}$ reported that the two genera exhibited a mean sequence similarity value of $96.6 \%$ in the $16 \mathrm{~S}$ rDNA. They also raised the question whether the differences between their $16 \mathrm{~S}$ rDNA sequences ( 2.9 to $4.8 \%$ ) were significant enough to classify them into two separate genera. Additional information on the sequences of the 16S-23S rRNA internal transcribed spacers (ITS) and the 23S rRNA gene may clarify this question. Comparison between Xanthomonas and Stenotrophomonas based on the partial sequence of the $5^{\prime}$ end of the $23 \mathrm{~S}$ rRNA gene indicated that the level of homology between their 23S rDNA sequences was approximately 92.8 to $95.9 \%$ (unpublished data). The homology value is relatively lower than that of $16 \mathrm{rDNA}$ sequence.

Based on cluster analysis of the rDNA (combination of $16 \mathrm{~S}$ and $23 \mathrm{~S}$ rDNA), the Xanthomonas strains were divided into two groups designated as subgroups 1 and 2 . The bootstrap values for the internal branch of the two subgroups were 99.9 and $100 \%$, respectively, indicating these two lineages are strong clusters. The obtained results suggest that the Xanthomonas strains tested here are phylogenetically grouped into two lineages. Subgroup 1 consisted of Xanthomonas axonopodis, $X$. campestris, $X$. fragariae and $X$. oryzae, while subgroup 2 comprised Xanthomonas albilineans and $X$. campestris. Unexpectedly, strains of $X$. campestris fell into both subgroups. Strains within subgroup 1 are pathovars alfalfae, begoniae, campestris, cannabis, carotae, citri, coriandri, cucurbitae, dieffenbachiae, glycines, incanae, malvacearum, mangiferaeindicae, nigromaculans, phaseoli, physalidicola, pruni, vesicatoria, vitians, zantedschiae and zinniae. Strains within subgroup 2 are pathovars cerealis, graminis, hyacinthi and translucens. Our results are similar to those of Manceau and Horvais ${ }^{15)}$, who have demonstrated that Pseudomonas syringae pathovars were distributed into three clusters based on PCR-RFLP of $r r n$ operon. Extensive studies based on protein profiles ${ }^{29)}$, fatty acid profiles ${ }^{31)}$, DNA hybridization $^{9,20,30,31)}$, RFLP of genomic $\mathrm{DNA}^{12)}$, and $\mathrm{rRNAs}^{3)}$ indicated that pathovars of $X$. campestris were heterogeneous. These facts were also supported by the obtained results here. Currently, molecular approaches are used in taxonomic studies; DNA-DNA hybridization is generally used for species delineation. Recently, Vauterin et al. ${ }^{27)}$ reclassified the genus Xanthomonas into 20 genomic species based on DNA-DNA hybridization study. Although not all the results of this study were in accordance with theirs, they were supported by those of Stackebrandt and Goebel ${ }^{21)}$, who reported that rDNA analysis should not replace delineation of species based on DNA-DNA hybridization.

On the basis of the 16S-23S rRNA internal transcribed spacers (ITS), a large polymorphism was detected by RFLPs, although the length of this region is shorter than that of the $16 \mathrm{~S}$ or $23 \mathrm{~S}$ rDNA. When the data obtained by ITS and rDNA analyses were combined, each $X$. campestris pathovar was discriminated. However, the exceptions were between $X$. campestris pv. citri and pv. glycines, and $X . c$. pv. malvacearum and pv. vitians. Cluster analysis showed that Xanthomonas strains tested were also divided into two groups, and members of each group were the same as those based on rDNAs. The presumption that Xanthomonas strains are phylogenetically grouped into at least two lineages was confirmed by this ITS analysis. Although $X$. albilineans of subgroup 2 by rDNA analyses corresponded to subgroup 2 by cluster analysis using ITS data, genetic distance between the species and other members was very great and the bootstrap value of the branch was low. This fact suggests that $X$. albilineans may be a third group designated as subgroup 3, though further study is required to clarify it.

Considering the differences between strains of subgroups 1 and 2, the former is mainly pathogenic to dicotyledonous plants, while the latter is composed of strains pathogenic only to monocotyledonous plants. In addition, members of subgroup 1 have an average $\mathrm{G}+\mathrm{C}$ content of 65 to $66 \mathrm{~mol} \%$, but those of subgroup 2 have an average $\mathrm{G}+\mathrm{C}$ content of $69 \mathrm{~mol} \%{ }^{8}$. $X$. albilineans is an exception in subgroup 2 , and its $\mathrm{G}+\mathrm{C}$ content is $64.2 \%^{8}$. However, other common features to distinguish the two groups are difficult to find.

The PCR-RFLP analysis of the $r m$ operon in this study appears to be a rapid, useful tool for evaluating the genetic relatedness of the genus Xanthomonas. Based on the results of this study, this method allows us to demonstrate that phylogenetically, the Xanthomonas strains tested here are grouped into at least two line- 
ages. Further research is needed to clarify the relationships such as the comparative analyses of pathogenicity related genes.

\section{Literature cited}

1. Adhikari, T.A., Vera Cruz, C.M., Zhang, Q., Nelson, R.J., Skinner, D.Z., Mew, T.W. and Leach, J.E. (1995). Genetic diversity of Xanthomonas oryzae pv. oryzae in Asia. Appl. Environ. Microbiol. 61 : 966-971.

2. Ausubel, F.M., Brent, R., Kingston, R.E., Moore, D.D., Seidman, J.G., Smith, J.A. and Struhl, K. (1987). Preparation of genomic DNA. In Current Protocols in Molecular Biology, Vol. 3, John Wiley \& Sons, New York, pp. 2.4.1-2.4.2.

3. Berthier, Y., Verdier, V., Guesdon, J.L., Chevrier, D., Denis, J.B., Decoux, G. and Lemattre, M. (1993). Characterization of Xanthomonas campestris pathovars by rRNA gene restriction patterns. Appl. Environ. Microbiol. 59 : 851-859.

4. Bragard, C., Verdier, V. and Maraite, H. (1995). Genetic diversity among Xanthomonas campestris strains pathogenic for small grains. Appl. Environ. Microbiol. 61: 1020-1026.

5. Brosius, J., Dull, T.J., Sleeter, D.D. and Noller, H.F. (1981). Gene organization and primary structure of a ribosomal RNA operon from Escherichia coli. J. Mol. Biol. 148: 107-127.

6. DeParasis, J. and Roth, D.A. (1990). Nucleic acid probes for identification of phytobacteria : identification of genus-specific $16 \mathrm{~S}$ rRNA sequences. Phytopathology $80: 618-621$.

7. Felsenstein, J. (1993). PHYLIP (Phylogeny Inference Package) version $3.5 \mathrm{c}$. Distributed by the author, Department of Genetics, University of Washington, Seattle.

8. Hauben, L., Vauterin, L., Swings, J. and Moore, E.R.B. (1997). Comparison of $16 \mathrm{~S}$ ribosomal DNA sequences of all Xanthomonas species. Int. J. Syst. Bacteriol. 47 : 328-335.

9. Hildebrand, D.C., Palleroni, N.J. and Schroth, M.N. (1990). Deoxyribonucleic acid relatedness of 24 xanthomonad strains representing 23 Xanthomonas campestris pathovars and Xanthomonas fragariae. J. Appl. Bacteriol. $68: 263-269$.

10. Hopfl, P., Ludwig, W., Schleifer, K.H. and Larsen, N. (1989). The 23S ribosomal RNA higher-order structure of Pseudomonas cepacia and other prokaryotes. Eur. J. Biochem. 185 : 355-364.

11. Laguerre, G., Allard, M.R., Revoy, F. and Amarger, N. (1994). Rapid identification of rhizobia by restriction fragment length polymorphism analysis of PCRamplified 16S rRNA genes. Appl. Environ. Microbiol. $60: 56-63$.

12. Lazo, G.R., Roffey, R. and Gabriel, D.W. (1987). Pathovars of Xanthomonas campestris are distinguishable by restriction fragment length polymorphism. Int. J. Syst. Bacteriol. 37 : 214-221.

13. Leite, R.P., Minsavage, G.V., Bonas, U. and Stall, R.E. (1994). Detection and identification of phytopathogenic Xanthomonas strains by amplification of DNA se- quences related to the hrp genes of Xanthomonas campestris pv. vesicatoria. Appl. Environ. Microbiol. 60: 1068-1077.

14. Maes, M., Garbeva, P. and Kamoen, O. (1996). Recognition and detection in seed of the Xanthomonas pathogens that cause cereal leaf streak using rDNA spacer sequences and polymerase chain reaction. Phytopathology $86: 63-69$.

15. Manceau, C. and Horvais, A. (1997). Assessment of genetic diversity among strains of Pseudomonas syringae by PCR-restriction fragment length polymorphism analysis or rRNA operon with special emphasis on $P$. syrin gae pv. tomato. Appl. Environ. Microbiol. 63 : 498-505.

16. Narvarro, E., Simonet, P., Normand, P. and Bardin, R. (1992). Characterization of natural populations of Nitrobacter spp. Using PCR/RFLP analysis of the ribosomal intergenic spacer. Arch. Microbiol. 157 : 107115.

17. Nelson, R.J., Baraoidan, M.R., Vera Cruz, C.M., Yap, I.V., Leach, J.E., Mew, T.W. and Leung, H. (1994). Relationship between phylogeny and pathotype for the bacterial blight pathogen of rice. Appl. Environ. Microbiol. 60 : 3275-3283.

18. Nesme, X., Vaneechoutte, M., Orso, S., Hoste, B. and Swings, J. (1995). Diversity and genetic relatedness within genera Xanthomonas and Stenotrophomonas using restriction endonuclease site differences of PCRamplified 16S rRNA gene. Syst. Appl. Microbiol. 18: 127-135.

19. Palleroni, N.J. and Bradbury, J.F. (1993). Stenotrophomonas, a new bacterial genus for Xanthomonas maltophilia (Hugh 1980) Swings et al. 1983. Int. J. Syst. Bacteriol. 43 : 606-609.

20. Palleroni, N.J., Hildebrand, D.C., Schroth, M.N. and Hendson, M. (1993). Deoxyribonucleic acid relatedness of 21 strains of Xanthomonas species and pathovars. J. Appl. Bacteriol. 75 : 441-446.

21. Stackebrandt, E. and Goebel, B.M. (1994). Taxonomic note: A place for DNA-DNA reassociation and $16 \mathrm{~S}$ rRNA sequence analysis in the present species definition in bacteriology. Int. J. Syst. Bacteriol. 44 : 846-849.

22. Stall, R.E., Beaulieu, C., Egel, D., Hodge, N.C., Leite, R.P., Minsavage, G.V., Bouzar, H., Jones, J.B., Alvarez, A.M. and Benedict, A.A. (1994). Two genetically diverse groups of strains are included in Xanthomonas campestris pv. vesicatoria. Int. J. Syst. Bacteriol. 44 : 4753.

23. Toschka, H.Y., Hopfl, P., Ludwig, W., Schleifer, K.H., Ulbrich, N. and Erdmann, V.A. (1987). Complete nucleotide sequence of a $23 \mathrm{~S}$ ribosomal RNA gene from Pseudomonas aeruginosa. Nucleic Acids Res. 15 : 7182.

24. Vandamme, P., Pot, B., Gillis, M., De Vos, P., Kersters, K. and Swings, J. (1996). Polyphasic taxonomy, a consensus approach to bacterial systematics. Microbiol. Rev. $60: 407-438$.

25. Vaneechoutte, M., De Beenhouwer, H., Claeys, G., Verschraegen, G., De Rouck, A., Paepe, N., Elaichouni, A. and Portaels, F. (1993). Identification of Mycobacterium species by using amplified ribosomal DNA restriction analysis. J. Clin. Microbiol. 31 : 2061-2065.

26. Vaneechoutte, M., Rossau, R., De Vos, P., Gillis, M., 
Janssens, D., Paepe, N., De Rouck, A., Fiers, T., Claeys, G. and Kersters, K. (1992). Rapid identification of bacteria of the Comamonadaceae with amplified ribosomal DNA-restriction analysis (ARDRA). FEMS Microbiol. Lett. 93 : 227-234.

27. Vauterin, L., Hoste, B., Kersters, K. and Swings, J. (1995). Reclassification of Xanthomonas. Int. J. Syst. Bacteriol. 45 : 472-489.

28. Vauterin, L., Hoste, B., Yang, P., Alvarez, A., Kersters, K. and Swings, J. (1993). Taxonomy of the genus Xanthomonas. In Xanthomonas (Swings, J.G. and Civerolo, E.L. eds.), Chapman \& Hall, London, pp. 157192.

29. Vauterin, L., Swings, J. and Kersters, K. (1991). Grouping of Xanthomonas campestris pathovars by SDS-PAGE of proteins. J. Gen. Microbiol. 137 : 1677-1687.

30. Vauterin, L., Swings, J., Kersters, K., Gillis, M., Mew, T.W., Schroth, M.N., Palleroni, N.J., Hildebrand, D.C. Stead, D.E., Civerolo, E.L., Hayward, A.C., Maraite, H., Stall, R.E., Vidaver, A.K. and Bradbury, J.F. (1990). Toward an improved taxonomy of Xanthomonas. Int. J. Syst. Bacteriol. 40 : 312-316.

31. Vauterin, L., Yang, P., Hoste, B., Pot, B., Swings, J. and Kersters, K. (1992). Taxonomy xanthomonads from cereals and grasses based on SDS-PAGE of proteins, fatty acid analysis and DNA hybridization. J. Gen. Microbiol. 138: 1467-1477.

32. Verdier, V., Dongo, P. and Boher, B. (1993). Assessment of genetic diversity among strains of Xanthomonas campestris pv. manihotis. J. Gen. Microbiol. 139 : 25912601.

33. Vinuesa, P., Rademaker, J.L.W., De Bruijn, F.J. and Werner, D. (1998). Genotypic characterization of Bradyrhizobium strains nodulating endemic woody legumes of the Canary islands by PCR-restriction fragment length polymorphism analysis of genes encoding $16 \mathrm{~S}$ rRNA (16S rDNA) and 16S-23S rDNA intergenic spacers, repetitive extragenic palindromic PCR genomic fingerprinting, and partial 16S rDNA sequencing. Appl.
Environ. Microbiol. 64 : 2096-2104.

34. Wayne, L.G., Brenner, D.J., Colwell, R.R., Grimont, P.A. D., Kandler, O., Krichevsky, M.I., Moore, L.H., Moore, W.E.C., Murrary, R.G.E., Stackebrandt, E., Starr, M.P. and Truper, H.G. (1987). Report of the Ad Hoc Committee on Reconciliation of Approaches to Bacterial Systematics. Int. J. Syst. Bacteriol. 37 : 463-464.

35. Woese, C.R. (1987). Bacterial evolution. Microbiol. Rev. 51: 221-271.

36. Yap, I.V. and Nelson, R.J. (1996). WinBoot: A program for performing bootstrap analysis of binary data to determine the confidence limits of UPGMA-based dendrograms. IRRI Discussion Paper Series 14. International Rice Research Institute, Manila, the Philippines.

\section{和 文 摘 要}

落合弘和・加来久敏：16S, $23 \mathrm{~S}$ rDNA および rDNA スペーサ 一の PCR-RFLP 解析に基づくXanthomonas 属 pathovar 間 の遺伝的関係

Xanthomonas 属細菌各 pathovar と Stenotrophomonas maltophilia の系統関係を明らかにするために, PCR で増幅し た 3 種類の DNA 断片，16S rDNA，23S rDNA と rDNA スぺ ーサー (ITS) についてそれぞれ 10 種類の制限酵素による PCR-RFLP 解析を行った。その結果，供試した Xanthomonas 属細菌は, それぞれ $16 \mathrm{~S}$ rDNA の多型解析では 7 つタイプ, $23 \mathrm{~S}$ rDNA の多型解析では 8 タイプが検出された。これら $2 つ$ の結果を総合すると，Xanthomonas 属細菌は 13 種類の rDNA 型に分類された。この rDNA 型に基づいたクラスター解析の結 果, 供試した Xanthomonas 属細菌は subgroup 1, 2 と命名した 2 つのグループに類別され，さらにそのクラスターは近縁属で ある Stenotrophomonas とは区別された。一方, ITS に基づく多

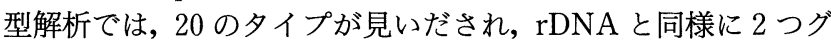
ループに類別された。また, おのおののグループに属する菌株群 は, rDNA の解析に基づくものと一致した。以上の結果から, Xanthomonas 属細菌は, 系統的には少なくとも2つのグループ で構成されていることが示唆された。 